\title{
Sequence variation of bovine mitochondrial ND-5 between haplotypes of composite and Hereford Breeds of beef cattle
}

\author{
SUTARNO \\ Department of Biology, Faculty of Mathematics and Natural Science. \\ Sebelas Maret University, Surakarta 57126
}

Received: 17 April 2002. Accepted: 30 April 2002

\begin{abstract}
The aims of the study were to: Investigate polymorphisms in the ND-5 region of bovine mitochondrial DNA in the composite and purebred Hereford herds from the Wokalup selection experiment, sequencing and compare the sequences between haplotypes and published sequence from Genebank. A total of 194 Hereford and 235 composite breed cattle from Wokalup Research Station were used in this study. The mitochondrial DNA was extracted using Wizard genomic DNA purification system from Promega. ND-5 fragment of mitochondrial DNA was amplified using PCR and continued with RFLP. Each haplotypes were sequenced. PCR products of each haplotype were cloned into pCR II, transformed, colonies selection, plasmid DNA extraction continued with cycle sequencing. Polymorphisms were found in both breeds of cattle in ND- 5 region of mitochondrial DNA by PCR-RFLP analysis. Sequencing analysis confirmed the RFLPs data.
\end{abstract}

(c) 2002 Jurusan Biologi FMIPA UNS Surakarta

Key words: ND-5 mitochondrial DNA, PCR-RFLP, sequencing, polymorphism.

\section{INTRODUCTION}

Genetic diversity is the basis for livestock breeding (Buis, Oldenbroek and Vanderwerf, 1994), because it is used as a starting point for the improvement of breeds by artificial selection. Understanding the extent and pattern of genetic variability among breeds may help in the development of more rational breeding programs and is a prerequisite to the informed conservation of genetic resources (Kidd et al., 1974). It thus the information on genetic diversity and genetic relationships among cattle breeds may be very useful in cattle breeding programs.

Advanced techniques of molecular biology have provided the opportunity to study genetic diversity within and among breeds at the single gene level (Baker and Manwell, 1991; Loftus et al., 1994b; MacHugh et al., 1994; Moazamigoudarzi et al., 1997). Many DNA markers, either of genomic DNA or cytoplasmic DNA, have been generated recently by utilizing molecular techniques. Mitochondrial DNA, a genetic information located outside nuclear cell, has become an area of interest for studying the maternal inheritance of many traits in livestock, as well as in population genetic studies. Avise (1994) has extensively reviewed the advantages of using mitochondrial DNA, a cytoplasmically inherited DNA, as a genetic marker in population studies. Mitochondrial DNA polymorphism has been reported within and between breeds of cattle (Bhat, Mishra and Bhat, 1990; Ron et al., 1990; Sutarno and Lymbery, 1997; Tanaka et al., 1995) and recently, Loftus et al. (1994a) used mtDNA polymorphisms to study the phylogeny of different breeds of cattle from Europe, Asia and Africa. For the application of studying mitochondrial DNA, except in phylogenetic studies, variation of mitochondrial DNA has been suggested to significantly correlate with fertility trait in beef cattle (Sutarno et al., 2002). 


\section{MATERIALS AND METHODS}

\section{Blood collection}

Blood was collected by venepuncture into a $50 \mathrm{ml}$ tube containing $2.5 \mathrm{ml}$ of $200 \mathrm{mM}$ EDTA as anticoagulant. $10 \mathrm{ml}$ of this blood was aspirated and stored at $-70^{\circ} \mathrm{C}$ for future reference. White blood cells were then isolated from the remaining $40 \mathrm{ml}$ of blood.

\section{Isolation of white blood cells}

Whole blood was dispensed into centrifuge tubes, and then spun at about $1500 \mathrm{~g}$ for $15-20$ minutes. The buffy coat was removed with a pipette, transferred to $10 \mathrm{ml}$ or $20 \mathrm{ml}$ centrifuge tubes, topped up with TE-1 buffer (10mM Tris, $1 \mathrm{mM}$ EDTA, pH 8) and centrifuged at $2000 \mathrm{~g}$ for 10-15 minutes. The pellet was resuspended in $1 \mathrm{ml}$ of TE-2 buffer (10mM Tris, $1 \mathrm{mM}$ EDTA and $100 \mathrm{mM} \mathrm{NaCl}, \mathrm{pH} 8.0$ ), transferred to $1 \mathrm{ml}$ Nunc storage tube, and frozen at $-84^{\circ} \mathrm{C}$.

\section{Extraction of mitochondrial DNA from white blood cells}

Mitochondrial DNA was extracted using the Wizard Minipreps DNA Purification System (Promega, Madison, USA). Mitochondrial pellets were prepared according to published methods (Welter, Dooley and Blin, 1989).

\section{PCR-RFLP}

All PCR amplification reactions were performed in an Omnigene thermocycler machine. The reactions were performed in a $50 \mathrm{ml}$ reaction mix consisting of $200 \mathrm{ng}$ of template DNA, $0.15 \mu \mathrm{M}$ each of the oligonucleotide primers, $200 \mu \mathrm{M}$ each dNTPs, $2 \mathrm{mM} \mathrm{MgCl} 2,10 \mathrm{x}$ buffer and 1.5 units Taq DNA polymerase (Biotech, Australia) in $0.6 \mu \mathrm{l}$ $\mathrm{PCR}$ reaction tube.

\section{PCR amplification of mitochondrial ND-5}

The ND-5 region, a part of the gene coding for NADH dehydrogenase sub-unit 5 (ND-5) were amplified by PCR, using primers ND-L / ND-R are described below:

ND-5 Primers:

ND-L: 5'-ATCCGTTGGTCTTAGGAACC-3' ND-R: 5'-TTGCGGTTACAAGGATGAGC-3'

All amplification reactions were performed in a 50 I reaction mix consisting of $200 \mathrm{ng}$ of template DNA, $0.15 \mu \mathrm{M}$ each of the oligonucleotide primers, $200 \mu \mathrm{M}$ each dNTPs,
$2 \mathrm{mM} \mathrm{MgCl} 2,10 \mathrm{x}$ buffer and 1.5 units Taq DNA polymerase (Biotech, Australia). Negative controls (lacking template DNA) were included in all reactions, and produced no products.

PCR amplification conditions for the mitochondrial ND-5 were as follows: one preliminary denaturation reaction was set at 94 ${ }^{\circ} \mathrm{C}$ for 6 minutes, followed by 30 amplification cycles, in which each cycle consisted of strand denaturation at $94{ }^{\circ} \mathrm{C}$ for $45 \mathrm{sec}$, annealing at $58^{\circ} \mathrm{C}$ for $45 \mathrm{sec}$ and primer extension at $72{ }^{\circ} \mathrm{C}$ for $1 \mathrm{~min}$, followed by a final polymerisation at $72{ }^{\circ} \mathrm{C}$ for 6 minutes.

\section{Extraction of plasmid DNA}

DNA containing inserts were extracted from selected liquid culture of overnight incubation using Wizard Plus Minipreps DNA Purification system (Promega, Madison, USA).

\section{Producing PCR products for cloning}

The conditions for PCR amplification of the ND-5 regions were the same as with $P C R$ for RFLP analysis, except the final step. To make sure all amplified DNA is double stranded with 3' A-overhangs, the final extension step was set for 10 minutes.

\section{Cloning into pCR II}

Fresh PCR products were electrophoresed on a $1 \%$ low melting agarose gel. Bands were excised and purified using Wizard PCR Preps (Promega). The purified fragments were then precipitated using $99 \%$ ethanol and $3 \mathrm{M} \mathrm{Na}$ acetate. DNA content was measured using a fluorometer.

The ratio between vector and insert is very important in determining the efficiency of ligation. Based on the fluorometer reading and the length (base pair) of PCR products, the amount of PCR product needed for ligation can be estimated using the formula given in the Invitrogen instruction manual. $1.1 \mathrm{ng}$ of ND-5 (A and B haplotype) were separately put in the microcentrifuge containing $1 \mu$ of $10 x$ ligation buffer, $2 \mu \mathrm{l}$ of pCR II vector $(25 \mathrm{ng} / \mu \mathrm{l})$, $4.9 \mu \mathrm{l}$ sterile water and $1 \mu \mathrm{l}$ T4 DNA ligase (4.0 Weiss units). The ligation reaction was incubated at $14^{\circ} \mathrm{C}$ overnight.

\section{Transformation}

Tubes containing the ligation reactions were centrifuged briefly and placed on ice. 
Vials of $0.5 \mathrm{M} \beta$-mercaptoethanol ( $\beta$-ME) and a $50 \mu \mathrm{l}$ vial of frozen One Shot competent cells (one for each ligation/transformation) were thawed on ice. $2 \mu \mathrm{l}$ of $0.5 \mathrm{M} \beta$-ME was pipetted into each vial of the competent cells and mixed by stirring gently with the pipette tip. $2 \mu \mathrm{l}$ of each ligation reaction was then pipetted into the competent cells and mixed by stirring with the pipette tip. The tubes were then incubated on ice for 30 minutes followed by heat shock for exactly 30 seconds in the $42^{\circ} \mathrm{C}$ water bath, and then placed on ice for 2 minutes. $450 \mu \mathrm{l}$ of SOC medium (2\% tryptone, $0.5 \%$ yeast extract, $10 \mathrm{mM} \mathrm{NaCl}, 2.5 \mathrm{mM} \mathrm{KCl}$, $10 \mathrm{mM} \mathrm{MgSO}_{4}, 20 \mathrm{mM}$ glucose, from: Invitrogen, San Diego, CA) were added into each tube. The tubes were then placed in a rotary shaking at $37^{\circ} \mathrm{C}$ for 1 hour at $225 \mathrm{rpm}$. The tubes with the transformed cells were placed on ice. $50 \mathrm{ml}$ and $200 \mathrm{ml}$ from each transformation tube was spread on separate, labeled Luria Bertani (LB) agar (1 \% tryptone, $0.5 \%$ yeast extract, $1 \% \mathrm{NaCl} ; \mathrm{pH} 7.0$ ) plates containing $50 \mu \mathrm{g} / \mathrm{ml}$ kanamycin and X-Gal. The plates were then left at room temperature for 1 hour for the liquid to be absorbed by the agar, inverted and placed in a $37^{\circ} \mathrm{C}$ room for 18 hours.

\section{Blue white selection of colonies}

After 18 hours incubation, blue and white colonies appeared on each agar plate. The white colonies contained inserts and were selected for further culture. Selection was done from the plates containing $50 \mu \mathrm{l}$ spreaded transformation mix. By using a sterile toothpick, a white colony was put into a $30 \mathrm{ml}$ sterile plastic tube containing $5 \mathrm{ml}$ liquid culture (LB broth). Ten colonies for each plate were taken into 10 culture tubes, and incubated in a rotary shaker $(225 \mathrm{rpm})$ at $37^{\circ} \mathrm{C}$ overnight.

\section{PCR selection}

After 4 hours incubation, $20 \mu \mathrm{l}$ of each culture tube were taken for PCR selection, and the tubes were returned immediately into the rotary shaker. Each $20 \mathrm{ml}$ sample was put into a separate microcentrifuge tube containing $1 \%$ Triton $\mathrm{X}$ in TE buffer $\mathrm{pH}$ 8.0. The tubes were then boiled at $97^{\circ} \mathrm{C}$ for 10 minutes followed by centrifugation at $14.000 \mathrm{rpm}$ for 5 minutes. $5 \mu \mathrm{l}$ of the supernatant from each tube was transferred into $20 \mu \mathrm{l}$ PCR reaction using M13 forward and reverse primers. The PCR products were then electrophoresed on a $1 \%$ agarose gel to check the incorporation of the insert in the amplified fragment.

\section{Plasmid DNA extraction from liquid culture}

DNA containing ND-5 ( $A$ and $B$ ) inserts were then extracted from selected liquid cultures using DNA Minipreps Plus (Promega). The amount of extracted DNA was then measured using a fluorometer to correctly estimate the amount of DNA used for cycle sequencing. The extension products were precipitated using $99 \%$ ethanol and $3 \mathrm{M}$ sodium acetate before sequencing.

\section{Purification of extension products}

Extension products were purified using the QIAquick PCR Purification Kit (Qiagen, Germany). The product were then stored at $20^{\circ} \mathrm{C}$ prior to sequencing.

\section{Cycle sequencing}

Mitochondrial ND-5 were sequenced using a dye-labeled terminator cycle sequencing kit supplied by Applied Biosystems. Aliquots of 2 $\mu l$ of double stranded DNA extracted from the cloned vector containing an insert of the Dloop were added into a microcentrifuge tube consisting of $8.0 \mu$ terminator ready reaction mix, 3.2 pmole primer and $\mathrm{dH}_{2} \mathrm{O}$ adjusted to final volume of $20 \mu \mathrm{l}$ followed by cycle sequencing reaction.

The cycle sequencing reaction was performed in a thermal cycler as follows: (1) Twenty five cycles of rapid thermal ramp to $96^{\circ} \mathrm{C}, 96^{\circ} \mathrm{C}$ for 30 seconds, rapid thermal ramp to $50^{\circ} \mathrm{C}, 50^{\circ} \mathrm{C}$ for 15 seconds, rapid thermal ramp to $60^{\circ} \mathrm{C}, 60^{\circ} \mathrm{C}$ for 4 minutes; (2) Rapid thermal ramp to $4^{\circ} \mathrm{C}$ and hold.

\section{RESULTS}

Restriction site polymorphisms in

mitochondrial ND-5

Polymorphism resulted from amplified ND-5 fragment digested using Spel enzyme, one of six enzymes used in this study, was presented in Figure 1.

The PCR products of the ND-5 were digested using 6 enzymes listed in Table 1 , and the cleavage patterns of those enzymes are shown in Table 1. 


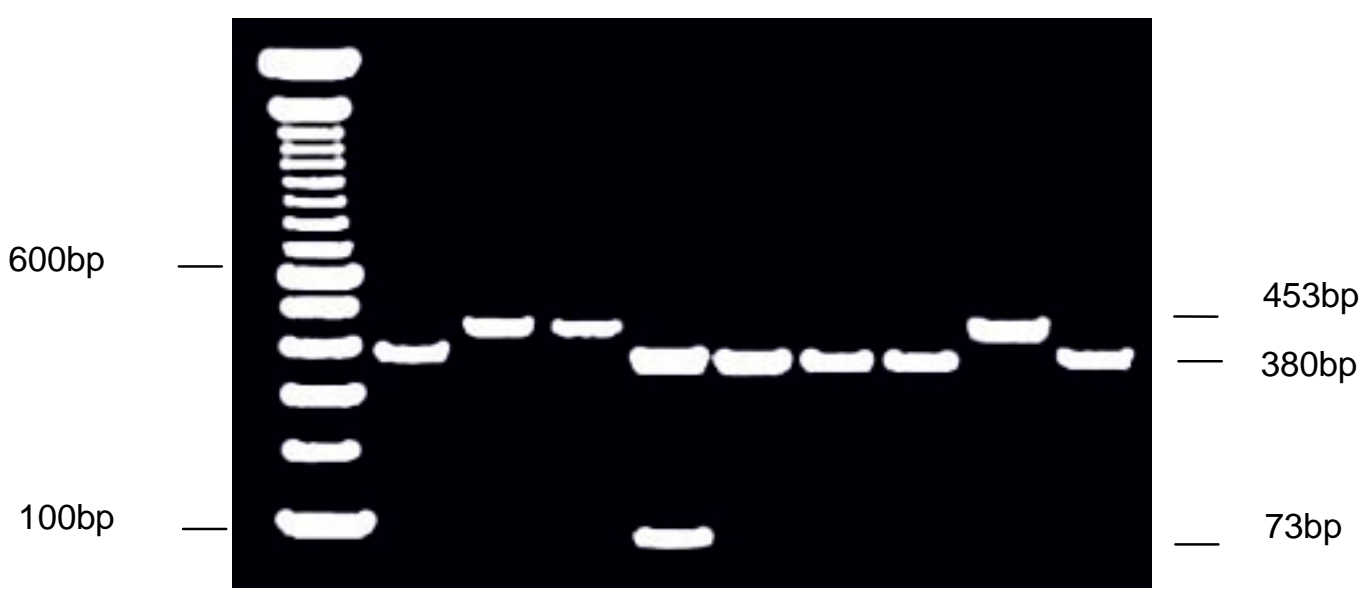

Figure 1. Gel photograph of an ethidium bromide stained agarose gel showing mitochondrial ND-5 polymorphism detected by PCR-RFLP using Spel.

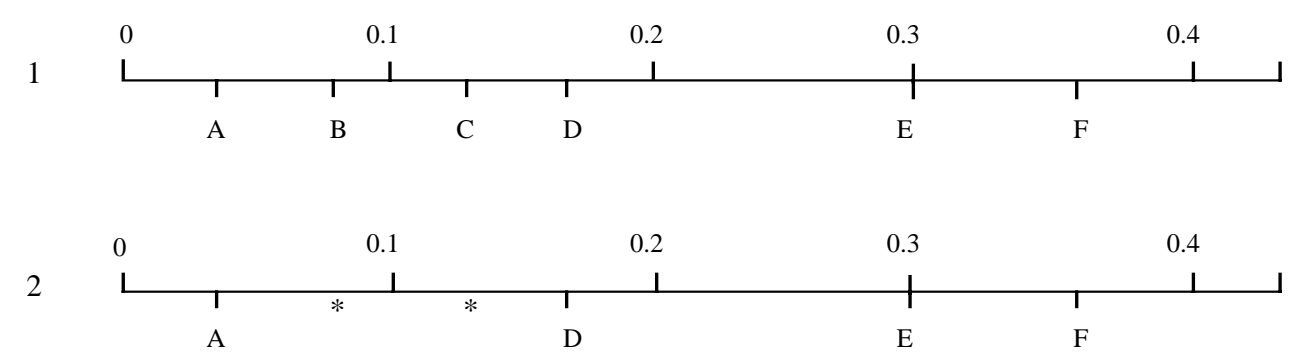

Figure 2. Restriction maps of ND-5. The enzymes are: BstXI (A), Spel (B), Hind III (C), SnaBI(D) Dral (E) and EcoRI (F). The restriction sites are according to the sequence of (Anderson et al., 1982). Polymorphic sites are indicated by *. The two haplotypes coded by the alleles in Table 3.6 are: 1 . (AAAAAA); and 2. (ABAABA).

Table 1. Restriction sites of 6 enzymes on 453-bp ND-5 fragment of mitochondrial DNA amplified by PCR.

\begin{tabular}{lccl}
\hline Enzyme & Allele & $\begin{array}{c}\text { No of } \\
\text { Restriction } \\
\text { site }\end{array}$ & $\begin{array}{c}\text { Fragment } \\
\text { size (kb) }\end{array}$ \\
\hline BstXI & A & 1 & $0.42,0.04$ \\
Spel & $\mathrm{A}$ & 1 & $0.38,0.08$ \\
& $\mathrm{~B}$ & 0 & 0.46 \\
HindIII & $\mathrm{A}$ & 1 & $0.33,0.13$ \\
& $\mathrm{~B}$ & 0 & 0.46 \\
SnaBI & $\mathrm{A}$ & 1 & $0.29,0.17$ \\
Dral & $\mathrm{A}$ & 1 & $0.30,0.16$ \\
EcoRI & $\mathrm{A}$ & 1 & $0.36,0.10$ \\
\hline
\end{tabular}

Two polymorphic sites were detected on ND-5 fragment using Spel and HindIII. Two haplotypes resulted, and the map of restriction sites of those haplotype were presented in Figure 2.

\section{Sequencing results}

Alignment of mitochondrial ND-5 sequences of different genotypes with the gene sequence from genebank (Anderson et al., 1982). Sequence similarities or differences are shown with or without asterik $\left(^{*}\right)$.

\section{DISCUSSION}

Recent developments in molecular techniques have resulted in an abundance of data on genetic polymorphisms from DNA analysis. These data will provide us with a better understanding of the nature of genetic variation within and between cattle breeds. PCR-RFLP analysis can detect the same type of polymorphisms as traditional RFLP analysis, but without the need for Southern 
CLUSTAL W (1.4) multiple sequence alignment.

\begin{tabular}{|c|c|}
\hline ND5-GENEBANK & ATCCGTTGGTCTTAGGAACCAAAAAATTGGTGCAACTCCAAATAAAAGTAATAAACATAT \\
\hline SUT-ND-5-A & ATCCGTTGGTCTTAGGAACCAAAAAATTGGTGCAACTCCAAATAAAAGTAATAAACATAT \\
\hline SUT-ND-5-B & 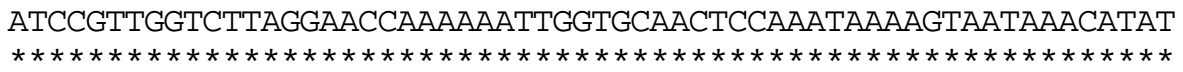 \\
\hline ND5-GENEBANK & 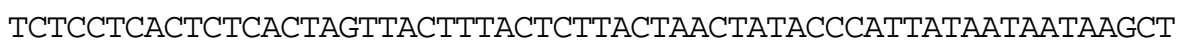 \\
\hline SUT-ND-5-A & 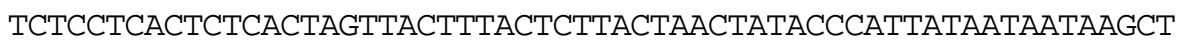 \\
\hline SUT-ND-5-B & 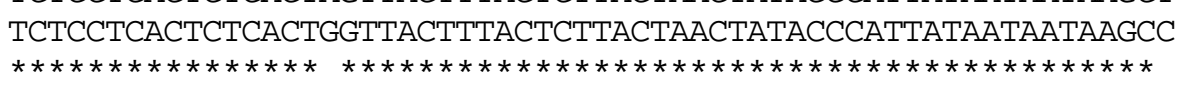 \\
\hline ND5 - GENEBANK & TTAАСАССТАСАААССТTССААСТАСССАСТСТАСGTAАAАACAGСТАТСТСАТАСGССТ \\
\hline SUT-ND-5-A & 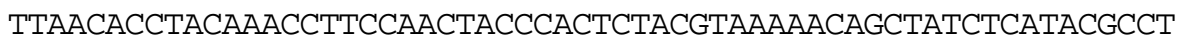 \\
\hline SUT-ND-5-B & 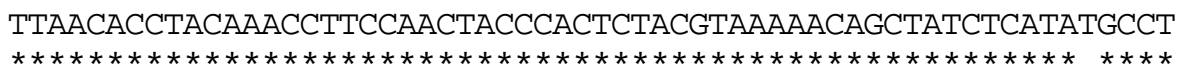 \\
\hline ND5 - GENEBANK & TCATTACCAGCATAATTCCСАCAATAATATTTATCCACTCAGGCCAAGAACTAATTATTT \\
\hline SUT-ND-5-A & TCATTACCAGCATAATTCCCACAATAATATTTATCCACTCAGGCCAAGGACTAATTATTT \\
\hline SUT-ND-5-B & 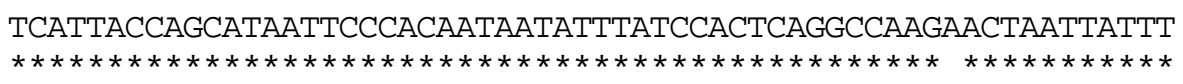 \\
\hline ND5-GENEBANK & 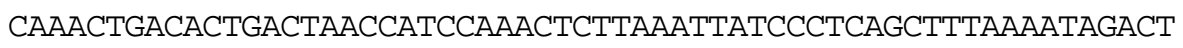 \\
\hline SUT-ND-5-A & 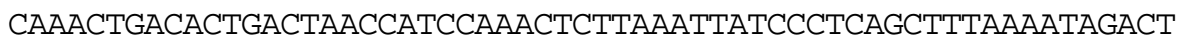 \\
\hline SUT-ND-5-B & 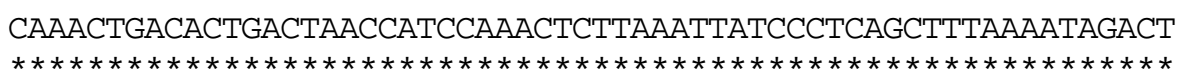 \\
\hline ND5 - GENEBANK & АTTTCTCAАTAАTATTTATCCCAGTAGCACTATTCGTCACATGATCTATTATAGAATTCT \\
\hline SUT-ND-5-A & ATTTCTCAATAATATTTATCCCAGTAGCACTATTCGTCACATGATCTATTATAGAATTCT \\
\hline SUT-ND-5-B & 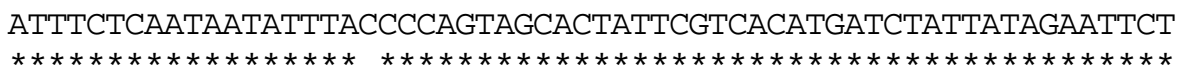 \\
\hline
\end{tabular}

blotting (Cushwa and Medrano, 1996), thus decreasing the time taken and increasing sensitivity (Weber and May, 1989). This method is therefore very useful for the study of genetic variation. Moreover, automatic sequence analysis, a relatively new method of analysis, has enable researchers to detect any mutation in the DNA the level of gene.

Polymorphisms were found in the mitochondrial ND-5 region with Spel and HindIII, confirming previous reports (Suzuki, Kemp and Teale, 1993; Watanabe et al., 1985b; Watanabe et al., 1989). New polymorphisms have been reported in the ND5 by PCR-RFLP analysis (Sutarno and Lymbery, 1997), and this polymorphism was reported to be significantly affect fertility trait in beef cattle (Sutarno et al., 2002). Compared to the standard bovine sequence of mitochondrial DNA (Anderson et al., 1982), by aligning the sequencing results with previous sequence from Genebank, these variant sequences have lost an Spel and HindIII sites in mitochondrial ND-5.
Genetic variation within breeds is important and its study has become a subject of interest in livestock species, as it has many applications in animal breeding and genetics. Archibald (1983) listed applications such as the identification of animals and parentage testing, gene mapping and identifying markers for performance traits. Since all phenotypic characters are influenced by the genetic information carried by DNA, DNA variation may be correlated with variation in performance traits. This idea is the basis for marker assisted selection (MAS), which has aroused much interest in recent years (Schwerin et al., 1995; Soller, 1994). Genetic variation, measured at the DNA level, can also be used as a check on the level of genetic variation in quantitative traits maintained within breeds. This will be extremely valuable in maintaining pools of genetic diversity, which artificial selection often acts to reduce (Archibald, 1983).

Another important application of genetic variation between breeds is to predict the 
crosses between breeds that will produce crossbreed offspring with maximum heterosis. Much more attention has been paid in recent years to the utilization of heterosis in beef cattle and other livestock species. However, because there are so many breeds that could be used for crossbreeding, it is impossible to experimentally cross and compare all breeds. The ability to predict the magnitude of heterosis effects between breeds is therefore crucially needed (Goddard and Ahmed, 1982). Since previous reports have indicated that heterosis does not increase in any simple way with increasing performance differences between parental populations (Robertson and Reeve, 1955), and relationships between heterosis and marker gene distance have been found (Ehiobu, Goddard and Taylor, 1990), the study of genetic variation at the DNA level in parental populations may increase the accuracy of predicting heterosis in crossbreeding.

\section{REFERENCES}

Anderson, S., M.H.L. De Bruijn, A.R. Coulson, I.C. Eperon, F. Sanger, and I.G. Young. 1982. Complete sequence on bovine mitochondrial DNA: conserved features of the mammalian mitochondrial genome. Journal of Molecular Biology 156: 683-717.

Archibald, A. L. 1983. Genetic variation-the raw material of animal breeding. ABRO report : 28-32.

Avise, J.C. 1994. Molecular Markers, Natural History and Evolution. New York: Chapman and Hall.

Baker, C.M.A. and C. Manwell. 1991. Population genetics, molecular markers and gene conservation of bovine breeds. In Hickman, E.G. (ed.) Cattle Genetic Resources Amsterdam: Elsevier Science Publishers B.V.

Bhat, P.P., B.P. Mishra, and P.N. Bhat. 1990. Polymorphism of mitochondrial DNA (mtDNA) in cattle and buffaloes. Biochemical genetics 28: 311318.

Buis, R.C., J.K. Oldenbroek, and J.H.J. Vanderwerf. 1994. Preserving genetic variance resources in commercial and non-commercial populations. Netherlands Journal of Agricultural Science 42: 2936.

Cushwa, W.T. and J.F. Medrano. 1996. Applications of the Random Amplified Polymorphic DNA (RAPD) assay for genetic analysis of livestock species. Animal Biotechnology 7: 11-31.

Ehiobu, N.G., M.E. Goddard, and J.E. Taylor. 1990. Prediction of heterosis in crosses between inbreed lines of Drosophila melanogaster. Theoretical and Applied Genetics 80: 321-325.

Goddard, M.E. and A.M. Ahmed. 1982. The use of the genetic distance between cattle breeds to predict the heterosis in crosses. Proceedings of the 2nd World Congress on Genetics applied to Livestock Production 8: 377-382.

Kidd, K.K., L. Osterhoff, L. Erhard, and W.H. Stone. 1974. The use of genetic relationships among cattle breeds in the formulation of rational breeding policies: an example with South Devon (South Africa) and Gelbvieh (Germany). Animal Blood Groups and Biochemical Genetics 4: 21-28.

Loftus, R.T., D.E. Machugh, D.G. Bradley, P.M. Sharp, and P. Cunningham. 1994b. Evidence for 2 independent domestications of cattle. Proceedings of the National Academy of Sciences of the United States of America 91: 2757-2761.

Loftus, R.T., D.E. Machugh, L.O. Ngere, D.S. Balain, A.M. Badi, D.G. Bradley, and E.P. Cunningham. 1994a. Mitochondrial genetic variation in European, African and Indian cattle populations. Animal Genetics 25: 265-271.

MacHugh, D.E., R.T. Loftus, D.G. Bradley, P.M. Sharp, and P. Cunningham. 1994. Microsatellite DNA variation within and among European cattle breeds. Proceedings of the Royal Society of London Series B: Biological Sciences 256: 25-31.

Moazamigoudarzi, K., D. Laloe, J.P. Furet, and F. Grosclaude. 1997. Analysis of genetic relationships between 10 cattle breeds with 17 microsatellites. Animal Genetics 28: 338-345.

Robertson, F.W. and E.C.R. Reeve. 1955. Studies in quantitative inheritance. VIII. Further analysis of heterosis in crosses between inbred lines of Drosophila melanogaster. Zeitschrift fur induktive Abstammungs-und Vererbungslehre 86: 439-458.

Ron, M., I. Genis, E. Ezra, and M. Shani. 1990. Polymorphism of mitochondrial DNA in IsraeliHolstein cattle. 4th World Congress on Genetics Applied to Livestock Production. Edinburgh, Scotland 14: $255-258$.

Schwerin, M., G. Brockmann, J. Vanselow, and H.M. Seyfert. 1995. Perspectives of molecular genome analysis in livestock improvement. Archiv fur Tierzucht Archives of Animal Breeding 38: 21-31.

Soller, M. 1994. Marker assisted selection - an overview. Animal Biotechnology 5. 193-207.

Sutarno, J.M. Cummins, J. Greeff, and A.J. Lymbery. 2002. Mitochondrial DNA polymorphisms and fertility in beef cattle. Theriogenology 6485: 1-8.

Sutarno and A.J. Lymbery. 1997. New RFLPs in the Mitochondrial Genome of Cattle. Animal Genetics 28: 240-241. 
Suzuki, R., S.J. Kemp, and A.J. Teale. 1993. Polymerase chain reaction analysis of mitochondrial DNA polymorphism in Ndama and Zebu cattle. Animal Genetics 24: 339-343.

Tanaka, K., T. Yamagata, J.S. Masangkay, M.O. Faruque, D. Vubinh, Salundik, S.S. Mansjoer, Y. Kawamoto, and T. Namikawa. 1995. Nucleotide diversity of mitochondrial DNAs between the swamp and the river types of domestic water buffaloes, Bubalus Bubalis, based on restriction endonuclease cleavage patterns. Biochemical Genetics 33: 137148.

Watanabe, T., Y. Hayashi, R. Semba, and N. Ogasawara. 1985b. Bovine mitochondrial DNA polymorphism in restriction endonuclease cleavage patterns and the location of the polymorphic sites. Biochemical Genetics 23: 947-957.

Watanabe, T., J.S. Masangkay, S. Wakana, N. Saitou, and T. Tomita. 1989. Mitochondrial DNA polymorphismin native Philippine cattle based on restriction endonuclease cleavage patterns. Biochemical Genetics 27: 431-438.

Weber, J.L. and P.E. May. 1989. Abundant class of human DNA polymorphisms which can be typed using the polymerase chain reaction. American Journal of Human Genetics 44: 388-396.

Welter, C., S. Dooley, and N. Blin. 1989. A rapid protocol for the purification of mitochondrial DNA suitable for studying restriction fragment length polymorphism (RFLP). Gene 83: 169-172. 